It is probably sufficient to say of this book that it is woll up to the standard of the previous volumes of the series, and it is therefore an essential requirement for any library of $\mathrm{a}$ biochemical laboratory where active research is being carried out.

D. H. NORTHCOTE

\section{Toxicity of Arsenic Compounds}

By W. D. Buchanan. (Elsovier Monographs on Toxic Agents.) Pp. viii + 155. (Amsterdam; Elsovier Publishing Company, 1962.) 25s.

$7 \mathrm{HF}$ toxic potentialitios of arsenical compounds are important to those concerned with environmental hoalth, in whatevor aspect. A monograph on this subject is a most valuable addition to the available general texts. The difficulty in trying to accomplish a task of this kind is to allocate an appropriate proportion of space to the historical aspects, the forensic and industrial problems, the preventive, clinical and therapeutic features and, particularly, the basic biochemical and pharmacological mechanisms of action. Inevitably something suffers, and it is usually the basic approach that is lacking or not fully adoquate. In the present instance much trouble has evidently been taken to avoid this pitfall. Above all, however, the author, who is a medical inspector of factories, has written an excellent training manual for inspectors of factories, using as its mainstay the records of H.M. Factory Inspectorate in Great Britain, and having as its principal preoccupation industrial poisoning by arsenicals. Within these limits it presents a elear, coherent and painstaking account of the subject.

What is lacking is any mention of recent developments in the toxicology of arsenic compounds, as for example their use as feedstuff additives for poultry and pigs, the problem presented by residual arsenic in the carcasses, the distinction betweon the fates of organic or proteinbound arsonic and inorganic arsenite in the body. Toxicology has deserted the Coroner's Court for the biochemical laboratory. It is becoming transformed into a new experimental science, but this book does not reflect the transformation. Perhaps for its intended purposo it was inadvisable that it should.

L. Golber(*

\section{Some Common Flowering Plants of Uganda}

By E. M. Lind and A. C. Tallantire. Pp. v+257+16 plates. (London: Oxford University Press, 1962.) $15 s$. papor bound; 25s. boards.

$\mathrm{U}$ NTIL now there has been no single moderately priced work which could be used by teachers, students or research workers wishing to identify the commoner plants of any part of tropical East Africa. The present clearly yet simply written, accurato and attractive book, in which are described some 500 species occurring in central Uganda, together with the 335 genera and 87 families to which they belong, therefore meets a very real need, and, while of the greatest valuo in Uganda itself, will also be useful in Kenya and Tanganyika. Keys are supplied to the families and to the genera of most large families. Troes and grasses, which are treated elsowhore, are omitted. Sections on how to collect and identify plants, a well-illustrated glossary and indexes in eight African langunges to somo 900 vernacular names aro cortain to prove valuable.

One hundred and sixty species are illustrated by line drawings and eightoen by coloured plates. It is regrettable that these illustrations are used simply to give a goneral impression of the specios concerned, with little or no attempt to clarify the salient characteristics of the family and genus in question. Thus, ten members of the Labiatao are illustrated, one in colour, but nowhere is the characteristic fruit of this farrily clearly shown, nor the meaning of the slightly ambiguous statement in the text 'stern usually square". Even where a key character, such as the biramous hairs of Indigofera, is illustrated, inadequate annotation leaves the point obseure.
As price is so important in determining the sales of a work of this kind, it may be noted that the papor binding is tough, attractive and hard-wearing. J. B. Gillewt

\section{Genetic Aspects of Dairy Cattle Breeding}

By Ivar Johansson. Pp. xii +259 . (Edinburgh and London: Oliver and Boyd, Ltd., 1962.) $40 s$.

TVAR JOHANSSON, formerly professor of animal breoding at the Royal Agrieultural College, Uppsala, and well known for his work on the subject in many countries, has set out the principles for the improvement of the standards of dairy cattle by the scientific application of the principles involved, particularly by the use of dovelopments in the integration of genetics and biometry during tho past four decades.

In a dozen chapters, each concernod with a special phase of the subject, ho describes present-day knowledge. Immunogeneties as applied to tho study of blood group characteristies and its application to inheritance; the use of monozygous twins; longevity, fertility and reproductivo disturbance; sterility and reduced fertility; the relation of body size, growth rate, muscular development and type of milk yield; characteristics of development of the udder and teats; milk and butter fat yield; composition of the milk; types of breoding.

This is a valuable book for the advanced reader. Much statistical matter is given.

\section{Advances in Small Animal Practice}

Vol. 3. Proceedings of the British Small Animal Vetorinary Association Congress, 1961. (Edited by Bruce V. Jones.) Pp. vii + 198. (London and New York: Pergamon Press, 1962.) 60s. net.

THE British Small Animal Veterinary Association, a relatively now body, has made a good start and the third volume of Advances in Small Animal Practice, covering its fourth congress, hold in 1961, has recently boen published. This body developed because of a need to give greater scope for the particular interests of veterinary surgeons specializing in small practice than was possible with bodies concerned with the wider general interests of the profession. Nearly thirty sessions are recorded and they concern some of the matters that are much under discussion in veterinary fields. Not all the papers were original in concept and certain of the subjects have been well to the fore in the literature elsewhere in recent years. Papers were read by visitors from the United States of America, France, Denmark, Italy and Swoden.

Surgery on small animals has mado great progress and it is well represented in this volume. The publications of this association are a welcome addition to the literature provided for the practising veterinary surgenon.

\section{W. POOL}

\section{Partial Differential Equations}

Proceedings of the Fourth Symposium in Pure Mathomatics of the Amorican Mathematical Society, held at the University of California, Berkeloy, California, April 21 22, 1960. Edited by Charles B. Morrey, Jr. Pp. vi + 169. (Providence, R.I.: American Mathematieal Society, 1961.) n.p.

TFEE American Mathematical Socicty's two series of Proceedings of symposia, in pure and in applied mathematios, are most useful, in that they offer in any single volume a collection of papers on present-day work centred around one main topic, which might otherwise have to be sought through a dozen different periodicals. In the present volume, there are sixteen papers all dealing with aspects of the strictly mathematical theory of partial differential equations. Though selection may be invidious, I found the papers by Aronszajn on associated norms and Bessel potentials, and that by Rosenbloom on the majorant method particularly interesting.

T. A. A. BROADBENT 